\title{
A Study on Customer Perception Towards Internet Banking: Identifying Major Contributing Factors
}

\author{
Divya Singhal and V. Padhmanabhan
}

Internet banking is becoming is increasingly becoming popular because of convenience and flexibility. The present paper explores the major factors responsible for internet banking based on respondents' perception on various internet applications. It also provides a framework of the factors which are taken to assess the internet banking perception.

Key words: Internet banking, online, Bank, perception, e-banking

\section{Introduction}

Internet banking is the term used for new age banking system. Internet banking is also called as online banking and it is an outgrowth of PC banking. Internet banking uses the internet as the delivery channel by which to conduct banking activity, for example, transferring funds, paying bills, viewing checking and savings account balances, paying mortgages and purchasing financial instruments and certificates of deposits (Haque et al, 2009). Internet banking is a result of explored possibility to use internet application in one of the various domains of commerce. It is difficult to infer whether the internet tool has been applied for convenience of bankers or for the customers' convenience. But ultimately it contributes in increasing the efficiency of the banking operation as well providing more convenience to customers. Without even interacting with the bankers, customers transact from one corner of the country to another corner.

There are many advantages of online Banking. It is convenient, it isn't bound by operational timings, there are no geographical barriers and the services can be offered at a minuscule cost (IAMAI's, 2006). Electronic banking has experienced explosive growth and has transformed traditional practices in banking (Gonzalez et al., 2008).

Private Banks in India were the first to implement internet banking services in the banking industry. Private Banks, due to late entry into the industry, understood that the establishing network in remote corners of the country is a very difficult task. It was clear to them that the only way to stay connected to the customers at any place and at anytime is through internet applications. They took the internet applications as a weapon of competitive advantage to corner the great monoliths like State Bank of India, Indian Bank etc. Private Banks are pioneer in India to explore the versatility of internet applications in delivering services to customers. 
As per prediction of Broadie et al(2007)the e- banking is leading to a paradigm shift in marketing practices resulting in high performance in the banking industry. Delivery of service in banking can be provided efficiently only when the back ground operations are efficient. An efficient back ground operation can be conducted only when it is integrated by an electronic system. The components like data, hardware, software, network and people are the essential elements of the system. Banking customers get satisfied with the system when it provides them maximum convenience and comfort while transacting with the bank. Internet enabled electronic system facilitate the operation to fetch these result.

An in-depth analysis would help to understand that internet enabled electronic bank system differentiates from traditional banking operation through faster delivery of information from the customer and service provider. Additionally, it has to be noted that the banking operations does not transfer physical currencies instead it transfer the information about the value for currencies. I-banks enable transfer of information more swiftly online. (Salawu et.al, 2007). In service organizations like banks, information flows more than physical items. In the commercial world, especially in most advanced societies today, money is rather carried in information storage medium such as cheques, credit cards and electronic means that in its pure cash form. According to christopher et al (2006), E banking has become an important channel to sell the products and services and is perceived to be necessity in order to stay profitable in successful.

The perception is the formed as a result of interpreting the experience. There is a growing interest in understanding the users' experience (Hiltunen et al., 2002 .); as it is observed as a larger concept than user satisfaction. From this perspective, assessing the user experience is essential for many technology products and services (Wilson \& Sasse, 2004)

Customers have started perceiving the services of bank through internet as a prime attractive feature than any other prime product features of the bank. Customers have started evaluating the banks based on the convenience and comforts it provides to them. Bankers have started developing various product features and services using internet applications.

\section{Objective}

The present study aims to explore the major factors responsible for internet banking based on respondents' perception on various internet applications.

Study also tries to examine whether there is any relation with the demographic variable (e.g. gender) and respondents' perception about internet banking; and, whether the user and non-user perception differs. 


\section{Methodology}

The study employs primary data as well as secondary data. Secondary data was collected from different published sources. Primary data was collected by structured survey. The survey was created online and link sent to the respondents from India using convenience sampling. The respondents, who were approached through email, were 80. Of these, 61 responses were received, giving a response rate of 76.0 percent.

In the questionnaire, various internet banking applications were included from previous research. Later, structured questionnaire containing 32 items was developed (18 for general perception and 15 for internet banking features) for the purpose of data collection. All items were measured by responses on a five-point Likert scale in agreement/ relevance with statements, ranging from $1=$ Strongly Disagree/ Completely Irrelevant to $5=$ Strongly Agree/ Completely Relevant. The analysis of primary data was carried out using Statistical Package for the Social Sciences (SPSS) 16.0 for windows.

\section{Sample Profile}

From the total respondents' $64 \%$ were males and $36 \%$ were females.

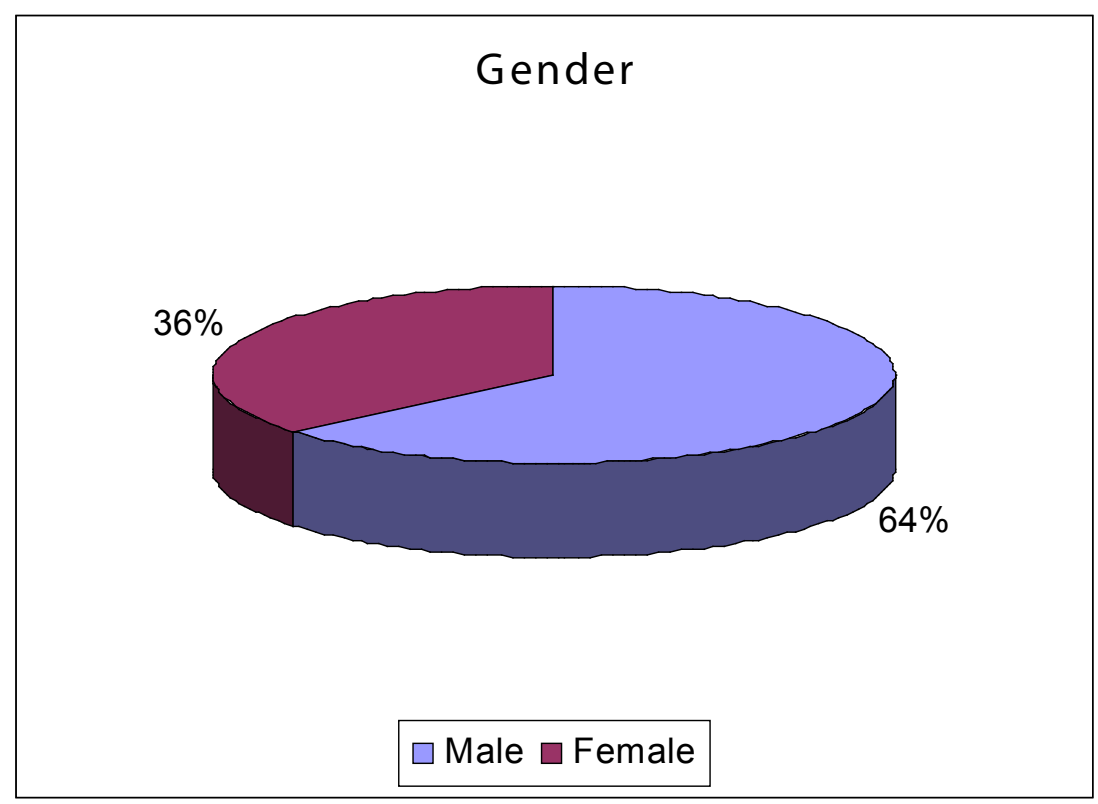


The chart below depicts the respondents classification based on user and non user criteria. Out of total respondents' 44 respondents were internet banking users' and 14 were non users.

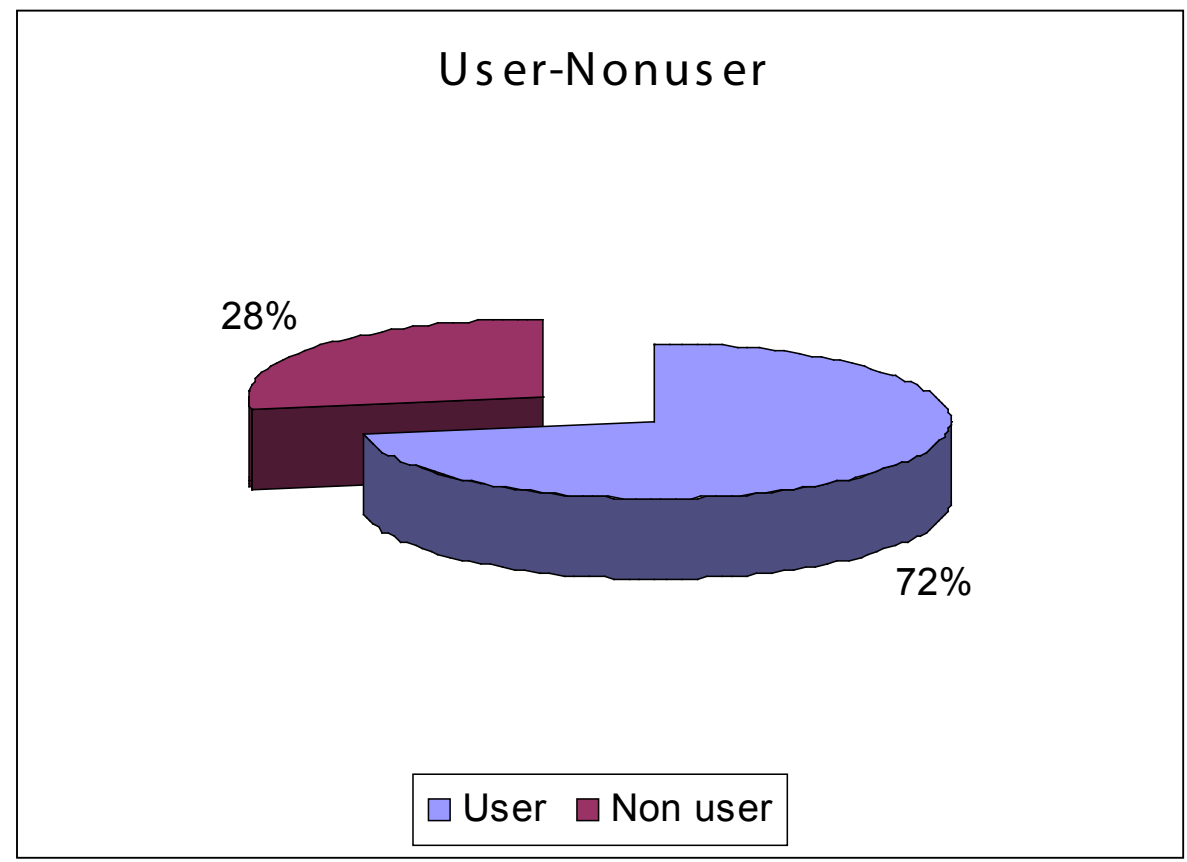

Most of the respondents belongs to the age group of 24-30, while 18-23 and 31-39 age group respondents were almost equal in number.

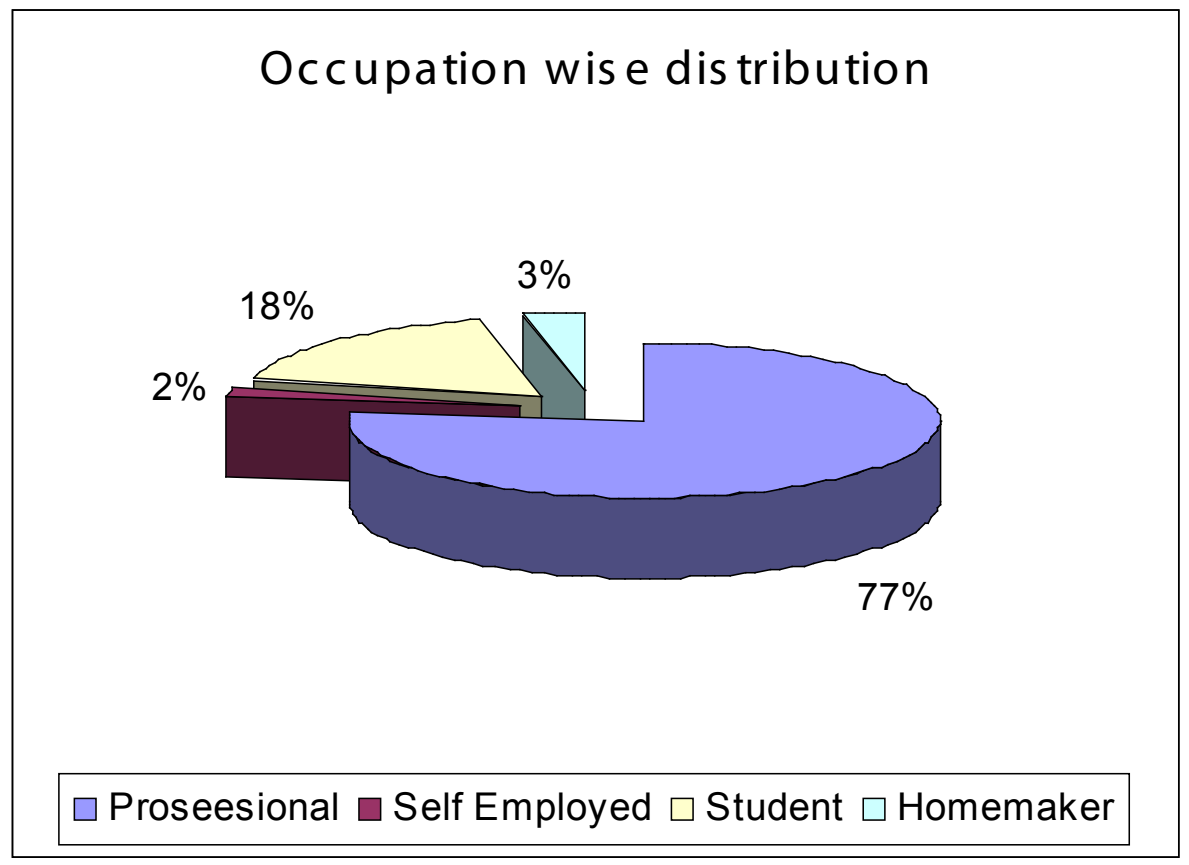


Out of total respondents' $77 \%$ were professional and $18 \%$ respondents were studying.

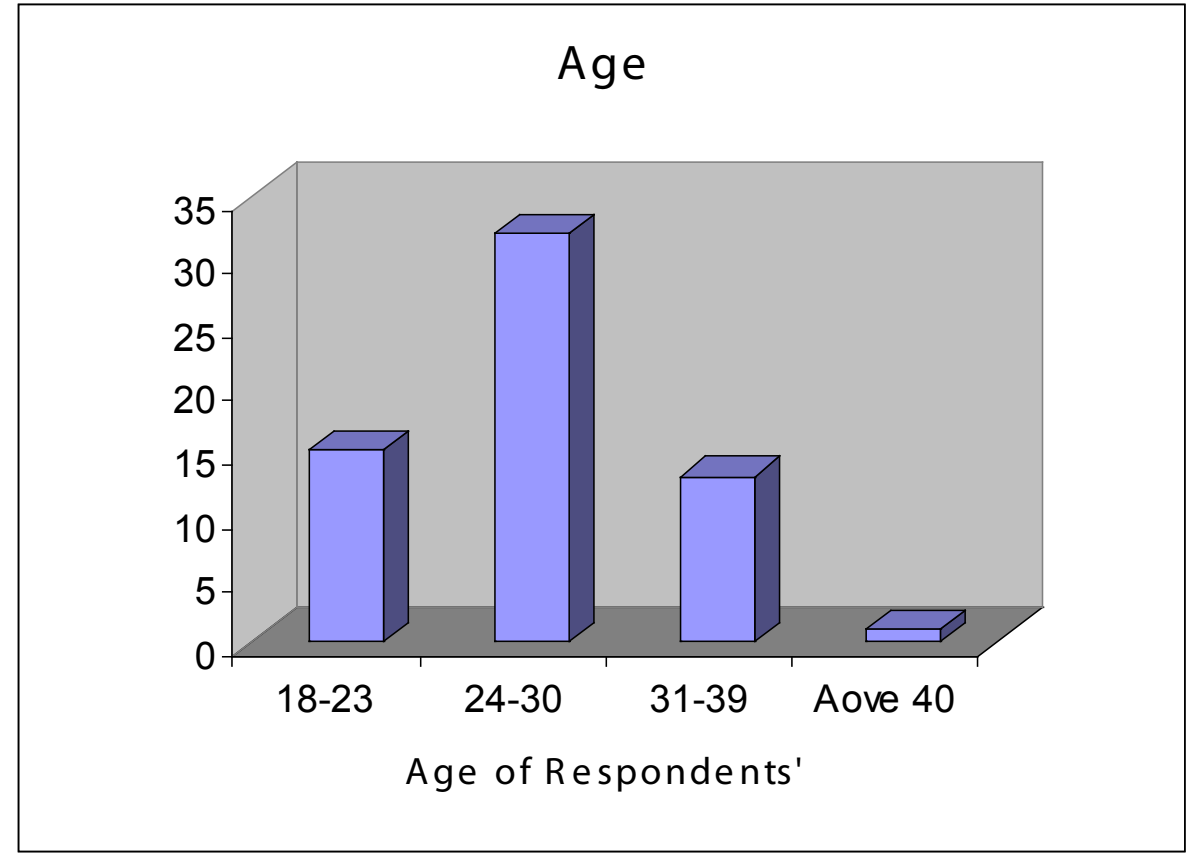

\section{Framework of the factors}

As mentioned that survey focuses on the finding the customers' perception on various internet application related with internet banking. Various factors which contribute to the customers' perception such as convenience, flexible virtual banking system, reliability, time factor, real time access to information, saving transaction cost, on-line bill payments, digital signature for security, faster transfer, easy to use, user friendly, low transaction fees, any time and anywhere banking facility, access to current and historical transaction data, facility of fund transfer to third party are taken for this study. These factors came from different studies.

\section{The Framework of the factors which are taken to assess the perception is as follows:}

1. Convenience way of operating banking transactions: Online banking is a highly profitable channel for financial institutions. It provides customers convenience and flexibility and can be provided at a lower cost than traditional branch banking (Williamson, 2006). The convenience of online banking is helping people gain greater control of their finances and contributing to changing patterns in cash withdrawal and day to day money management. (Beer, 2006)

2. Flexible virtual banking system: Financial institutions have spent a great deal of time and money developing online banking functionality to allow customers an easy and 
convenient way to manage their money (Williamson, 2006). A customer can check balance by logging into banks website through a user name and password. In this way he can enquire balance, status of cheques, perform funds transfers, order drafts, request issue of cheque books etc ( Srivastava,2008)

3. Reliability: Jun and cai (2001) identified one of the very important service quality dimensions of i-banking service quality is reliability. The online banking environment has grown tremendously over the past several years and will continue to grow as financial institutions continue to strive to allow customers to complete money transfers, pay bills, and access critical information online. During this same time, online banking has been plagued by Internet criminals and fraudsters attempting to steal customer information. Phishing, pharming, and other types of attacks have become well known and are widely used as a means for fraudsters to obtain information from customers and access online banking accounts. As a result, authenticating customers logging onto their online banking service has become a crucial concern of financial institutions (Gregory D. Williamson, 2006)

4. Time factor: Liu and Arnett in their study identified time factor as one of the prime factor that in Internet banking service quality feature for the customers. Saving time is an importance factor which influences the customers prefers to use i-banking. (Beer, 2006 ). Banks can make the information of products and services available on their site, which is, an advantageous proposition. Prospective customer can gather all the information from the website and thus if he comes to the branch with queries it will be very specific and will take less time of employee (Srivastava, 2006).

5. Real time access to information: The banks started i-banking initially with simple functions such as real time access to information about interest rates, checking account balances and computing loan eligibility. Then, the services are extended to online bill payment, transfer of funds between accounts and cash management services for corporate. (Sadique et al, 2009)

6. Saving transaction cost: Improving customer service, increasing market reach and reducing costs are now basic expectations of Internet banking services. If consumers are to use new technologies, the technologies must be reasonably priced relative to alternatives. Otherwise, the acceptance of the new technology may not be viable from the standpoint of the consumer (Suganthi et. al, 2001). Internet banking model offers advantages for both banks and customers. The Internet provides the banks with the ability to deliver products and services to customers at a cost that is lower than any existing mode of delivery.

7. On-line bill payments: The most popular online transaction through internet banking 
is funds transfer/bill payment (Beer, 2006). Of the twenty-two million users in US, twenty percent or 4.6 million people regularly used online bill payment services offered by the top ten financial institutions. This report also highlighted that the usage of online bill payment services increased by thirty-seven percent at the end of the first quarter 2004 (Strasburg, 2005).

8. Digital signature for security: In a survey conducted by the Online Banking Association, member institutions rated security as the most important issue of online banking. There is a dual requirement to protect customers' privacy and protect against fraud (Mishra). Digital signature is a precautionary measure to prevent malpractices and tampering the information. It is a form of enhanced authentication (Williamson, 2006). Nearly one in 5 customers were victims of identity theft and fraud (TriCipher, 2007)

9. Faster transfer: Another important factor that contributes the framework of the perception is the faster transfer of fund. The fundamental advantage of the internet banking is the transfer of the information about the money's worth to any place at any time with a mouse click's distance.

10. Easy to use and user friendliness: Ease of use is another important determinant for the customer preferring the internet banking (Beer, 2006). In a study conducted by Cooper (1997); reported that ease of use of innovative product or service as one of the three important characteristics for adoption from the customer's perspective. The user friendliness of domain names as well as the navigation tools available in the web-sites is an important determinant for ease of use. The design of the web-sites with appropriate use of graphical user interface is also considered as an important determinant. (Cooper, 1997) It is also worth noting that proper navigation attributes and search facility will also certainly be helpful to consumers when they surf the Internet. In addition, the level of interactivity of the site will certainly have an effect on the consumers' perception of the user friendliness of the Internet (Suganthi et. al, 2001)

11. Low transaction fees: Another factor that would stand in the way of consumer adoption of Internet banking is the cost factor. In Internet banking, two types of costs are involved. First, the normal costs associated with Internet access fees and connection charges and secondly the bank fees and charges (Suganthi et. al, 2001). These two types of costs shape the perception of the customers.

12. Any time and anywhere banking facility: Online banking users say that convenience is the most important factor, online banking lets them access their accounts from anywhere and at any time (IAMAI's, 2006) 
13. Access to current and historical transaction data: According to IAMAI report's - online banking '2006', customers prefer to view account balances, transaction history and updates get e-statements, credit card and debit card transaction history and updates, checking the status of their credit card accounts, viewing information regarding their demat account, information on their fixed deposits.

14. Facility of fund transfer to third party: According to IAMAI report's - online banking 2006, majority of the customers prefer on-line banking channels to transfer funds to third party.

15. Queue management: One among the important dimensions of e-banking service quality is queue management (Joseph et al.. 1999).

\section{Data Analysis and Results}

Factor Analysis was performed with 15 statements related with internet banking features. The Kaiser-Meyar-Olkin(KMO) for was .658 and significant Barlett's Test of Sphericity supported the use of factor analysis in order to extract independent variables associated with the internet baking. The degree of common variance among the fifteen variables is "mediocre" which reflects if a factor analysis is conducted, the factors extracted will account for fare amount of variance but not a substantial amount.

An exploratory principal component factor analysis was done using SPSS 16.0. Varimax rotation was used to identify the underlying factors for internet banking features. Items with eigen values greater than one were extracted and all factor loading greater than 0.5 were retained. Fifteen items yielded 5 factors explaining 74.10 percent of variance as shown in table 1.

\begin{tabular}{|c|c|c|c|c|}
\hline \multicolumn{2}{|c|}{ Table-1: Rotated Component Matrix } \\
\hline Factors & Items & $\begin{array}{c}\text { Factor } \\
\text { Loadings }\end{array}$ & $\begin{array}{c}\text { Variance } \\
\text { Explained }\end{array}$ & $\begin{array}{c}\text { Reliability } \\
\text { (Cronbach's Alpha) }\end{array}$ \\
\hline \multirow{3}{*}{ 1. Utility request } & & & & \\
\cline { 2 - 3 } & & & \multirow{2}{*}{18.848} & $.799 / .801$ \\
\cline { 2 - 3 } & & & & \\
\cline { 2 - 3 } 2. Security & & & \multirow{2}{*}{15.850} & .846 \\
\cline { 2 - 3 } & & & & \\
\cline { 2 - 3 } & & & & \\
& & & & \\
\end{tabular}




\begin{tabular}{|c|c|c|}
\hline \multirow{3}{*}{$\begin{array}{l}\text { 3. Utility Transac- } \\
\text { tion }\end{array}$} & \multirow[b]{3}{*}{15.055} & \multirow[b]{3}{*}{.786} \\
\hline & & \\
\hline & & \\
\hline \multirow[t]{2}{*}{ 4. Ticket booking } & \multirow[b]{2}{*}{14.205} & \multirow[b]{2}{*}{.920} \\
\hline & & \\
\hline \multirow[t]{2}{*}{ 5. Fund Transfer } & \multirow[b]{2}{*}{15.850} & \multirow[b]{2}{*}{.570} \\
\hline & & \\
\hline & 74.105 & \\
\hline
\end{tabular}

The major five independent set of factors associated with the internet banking features are extracted from the factor analysis and explained in brief:

Utility Request: Three out of four items loadings on this factor relate to 'utility request' dimension of internet banking. The respondents felt that these requests through online banking are important ones.

Security: security as the most important issue of online banking. The items loadings on this factor relate to security aspect.

Utility Transaction: Past researches indicates that online bill payment service is very important feature of online banking and people are effectively using this service. Researches also indicate that users for bill payments are increasing. People are also making online deposits and account opening through this.

Ticket Booking: Ticket booking is another important feature of internet banking. Now, people need not visit booking reservation centers any more, they can buy air and train tickets online using Internet Banking Facility.

Fund Transfer: Fund transfer and account statement is clubbed together as one factor and they are explaining 15.85 percent of variance.

General perception about internet banking was gauged by 18 items. Out of which seven items were related with convenience and flexibility and 8 items were related with transaction related benefits. All items were measured on a scale of 1 to 5 . From the questionnaire convenience and flexibility related items clubbed together and average score taken to gauge the respondents' perception about convenience factor. Out of total respondents $81 \%$ respondents felt that internet banking is very convenient and flexible banking. And same percentage i.e. $81 \%$ from total users agrees or strongly agrees that internet banking is convenient. They felt that it gives benefits like no queuing in bank and one can do anytime and anywhere banking. Approx 69 percent of total respondent agreed that internet banking has transaction related benefits. These benefits include efficient and speedy transfer of funds with lower transaction cost. And, with internet banking one can check transaction details 
regularly without any hassle.

\begin{tabular}{|c|c|c|}
\hline Factors & Items & Cronbach Alpha \\
\hline $\begin{array}{l}\text { Convenient and } \\
\text { flexibility }\end{array}$ & $\begin{array}{l}\text { - Convenient way of operating banking } \\
\text { transactions } \\
\text { - A very flexible virtual banking system } \\
\text { - Saves time as compared to conventional bank } \\
\text { ing } \\
\text { - No queuing in bank branches } \\
\text { - Easy to use } \\
\text { - User friendly } \\
\text { - Anytime and anywhere banking facility }\end{array}$ & 0.760 \\
\hline $\begin{array}{l}\text { Transaction re- } \\
\text { lated benefits }\end{array}$ & $\begin{array}{l}\text { - } \\
\text { - Traves a lot transaction cost } \\
\text { - It has lower transaction fees } \\
\text { - It allows speedy transfer } \\
\text { - It allows easy access to transaction data } \\
\text { both recent and historical } \\
\text { - I can check my transaction details and } \\
\text { statement regularly } \\
\text { - It gives facility of fund transfer to third } \\
\text { party }\end{array}$ & 0.819 \\
\hline
\end{tabular}

When asked 'Digital signature is best way to have security', $36 \%$ of total respondents agrees while only $22 \%$ strongly agrees with this. However, $63 \%$ of internet banking users either agrees or strongly agrees that digital signature is best way to have security. Out of total Male respondents $64 \%$ while $50 \%$ of total female respondents either agrees or strongly agrees that digital security is best way to have security and When asked that internet banking is most reliable only $9 \%$ users strongly agrees with this and $26 \%$ users agrees with the statement. Out of total respondents only $11 \%$ strongly agrees about the reliability of internet banking. ANOVA results for assessing perception about internet banking with age and gender showed no difference.

\section{Limitations and Future Research}

Although this research is primarily based on the primary data from the users and non users of Internet banking, the findings cannot be generalized, as the research is based on non probability sampling. This study has successfully examined the major factors responsible for internet banking based on respondents' perception on various internet applications; future research may include examining the factors importance. Future research may also consider the impact of other demographic variable like education. 


\section{Conclusions}

Thus, the analysis done with the help of statistical tools clearly indicate the factors responsible for internet banking. Factor analysis results indicate that 'utility request', 'security', 'utility transaction', 'ticket booking' and 'fund transfer' are major factors. Out of total respondents' more than $50 \%$ agreed that internet banking is convenient and flexible ways of banking and it also have various transaction related benefits. Thus, Providing Internet banking is increasingly becoming a "need to have" than a "nice to have" service. (http://www.banknetindia.com)

\section{References}

Ahasanul Haque et al (2009). Issues of E-Banking Transaction: An Empirical Investigation on Malaysian Customers Perception. Journal of applied Sciences. (Retrived from www.ebsco.com on 20 March 2009)

Beer Stan (2006). Customers Preference on Internet Banking, Survey (Retrieved from http://www.itwire.com/ content/view/4570/53 on 20 March 2009)

Brodie, H Winklhofer et. al (2007). Is e-marketing Coming of Age? An Examination of the Penetration of emarketing and Firm Performance. J. Innterac. Market, 21:2-21

Christopher, G. C.Mike, L. Visit and W.Amy (2006). A Logit Analysis of Electronic Banking in New Zealand. Int. J. Bank Market, 24:360-383

Cooper, R.G. (1997). Examining Some Myths About New Product Winners in Katz, R. (Eds), The Human Side of Managing Technological Innovation, Oxford, pp.550-60. (Retrieved from www.ebsco.com)

Gonzalez, M.E et al (2008). An Alternative Approach in Service Quality: An E-Banking Case Study. Quality Manage, 15: 41-48.

Gregory D. Williamson (2006). Enhanced Authentication In Online Banking, Journal of Economic Crime Management, Volume 4, Issue 2, http:/www.utica.edu/academic/institutes/ecii/publications/articles/ 51D6D996-90F2-F468-AC09C4E8071575AE.pdf on 18 March 2009

Hiltunen, M., Laukka, M., \& Luomala, J. (2002). Mobile User Experience. Helsinki: IT Press

Joseph, M., McClure, C. and Joseph, B.(1999). Service Quality in Banking Sector: The Impact of Technology on Service Delivery. International Journal of Bank Marketing, 17( 4):182-191

Jun, M. and Cai, S. (2001). The key Determinants of Internet Bank Service Quality: a Content Analysis, International Journal of Bank Marketing, 19(7): 276-291

Lindgaard \& Dudek C. (2003). What is This Evasive Beast We Call User Satisfaction. Interacting with Computers, $15,429-452$

Mishra A. K. (NK) (2009). Internet Banking in India-Part I. Retrieved from http://www.banknetindia.com/ banking/ibkg.htm on 18 March 2009

Mohammed Sadique Khan, Siba Sankar Mahapatra and Sreekumar(2009). Service Quality Evaluation in Internet Banking: An Empirical Study in India, Int. J. Indian Culture and Business Management, 2(1)

Rafiu Oyesola Salawu et.al, (2007). The Emergence of Internet Banking in Nigeria: An Appraisal. Information Technology Journal 6 (4): 490-496

Srivastva Saurabh (2009). Internet Banking - A Global Way to Bank, Retrieved from http://www.indianmba. com/Faculty_Column/FC908/fc908.html on 18 March 2009

Suganthi, Balachandher, and Balachandran, (2001) Internet Banking Patronage: An Empirical Investigation of Malaysia. Journal of Internet Banking and Commerce, 6 (1). Retrieved from http://www.arraydev. com/commerce/JIBC/0103_01.htm

TriCipher Consumer Online, Banking Study, T ri Cipher Solution Series. March 2007

IAMAI's Report on Online Banking 2006 Retrieved from http://www.iamai.in/Research.aspx?Fileid=r8_home. htm\&rid $=8$

http://www.banknetindia.com/banking/ibkgintro.htm Accessed on March 20, 2009 